Elżbieta Paszyńska', Tomasz Dąbkowski², Katarzyna Leszczyńska³, Justyna Otulakowska-Skrzyńska', Szymon Rzątowski', Anna Pawłowska-Lis' ${ }^{1}$, Aneta Olszewska' ${ }^{4}$, Anna Ratoń ${ }^{5}$, Maria Gawriołek'

\title{
Niefluorkowe systemy do remineralizacji zębów
}

\author{
Nonfluoride systems for teeth remineralization \\ 1 Zakład Stomatologii Zintegrowanej, Katedra i Klinika Stomatologii Zachowawczej i Endodoncji, \\ Uniwersytet Medyczny im. Karola Marcinkowskiego w Poznaniu \\ ${ }^{2}$ Centre Dentaire Dentego Roubaix, Francja \\ ${ }^{3}$ Niepubliczny Zakład Opieki Zdrowotnej „Expertus“, Poznań \\ ${ }^{4}$ Pracownia Wad Rozwojowych Twarzy, Katedra i Klinika Chirurgii Stomatologicznej i Periodontologii, \\ Uniwersytet Medyczny im. Karola Marcinkowskiego w Poznaniu \\ ${ }^{5}$ Prywatna Praktyka Lekarska „Orto-Dent", Katowice
}

DOI: http://dx.doi.org/10.20883/df.2018.30

\begin{abstract}
STRESZCZENIE
Pomino że ślina ludzka posiada zdolności remineralizacyjne, ze względu na obecność podstawowych składników mineralnych i pierwiastków śladowych, jej działanie w przypadkach próchnicy początkowej jest niewystarczające. Konieczne jest wzmocnienie tego procesu nie tylko przez fluor zawarty w pastach do zębów, ale poprzez nowe środki remineralizujące wapniowo-fosforanowe, które mogą wpływać na przywrócenie utraconych minerałów szkliwa na drodze wymiany jonowej, jak i mechanicznego wbudowywania w krystaliczną strukturę szkliwa. Olbrzymia ilość badań nad przydatnością materiałów zdolnych do remineralizacji szkliwa przekonuje o możliwości zastosowania ich w stomatologii. Wśród wprowadzonych obecnie do sprzedaży komercyjnej należy wyróżnić takie środki, jak fosforan trójwapniowy (TCP), fosforokrzemian wapniowo-sodowy, arginina-węglan wapnia, amorficzny fosforan wapnia w kompleksie CPP-ACP oraz nanohydroksyapatyt (HA/HAP). Jednakże, najbardziej niezależnym biomateriałem, który by swym składem, budową i wynikającymi właściwościami przypominał minerały ludzkiego zęba wydają się syntetyczne nanohydroksyapatyty. Przedstawione w pracy wyniki aktualnych badań in vitro i in vivo mogą być cenną wskazówką dla studentów stomatologii, a także praktykujących lekarzy dentystów.
\end{abstract}

Słowa kluczowe: remineralizacja zębów, próchnica początkowa, niefluorkowe systemy, nanohydroksyapatyty, szkliwo.

\section{ABSTRACT}

It will be remembered that human saliva has remineralization capabilities, due to the presence of basic minerals and trace elements, however in cases of initial caries its action is insufficient. It is necessary to strengthen this process not only by fluoride contained in toothpastes, but through new calcium-phosphate remineralizing agents that can affect the restoration of lost enamel minerals by ion exchange and mechanical incorporation into the crystalline structure of the enamel. The enormous amount of research on the usefulness of materials capable to enamel remineralization convinces us about possible use of them in dentistry. Among the currently introduced for commercial sale, we should distinguish such agents as tricalcium phosphate (TCP), calcium-sodium phosphosilicate, arginine-calcium carbonate, amorphous calcium phosphate in the CPP-ACP complex, and nanohydroxyapatite (HA/HAP). However, the most independent biomaterial that would be the composition, construction and resulting properties of resemblance to the minerals of the human tooth is synthetic nanohydroxyapatite. The results of current in vitro and in vivo studies presented in this paper can be a valuable guide for dental students as well as practicing dentists.

Keywords: remineralization of tooth, initial caries, nonfluoride systems, nanohydroxyapatite, enamel.

\section{Wstęp}

Badania ostatnich lat procesu remineralizacji zębów koncentrowały się na działaniu fluorków. Stąd fluor stał się niewątpliwie podstawowym pierwiastkiem, tzw. złotym standardem w prewen- cji próchnicy. Jednak już na początku ubiegłego wieku obserwowano szkodliwe działanie fluorków wpływające na wygląd i budowę zębów spowodowane przekroczeniem dawek tego pierwiastka na drodze endogennej/egzogennej w okresie rozwo- 
ju zębów [1, 2]. Ustalono, że krytycznym okresem dla rozwoju przewlekłego zatrucia związkami fluorków (fluorozy) jest pierwsze 8 lat życia człowieka $[3,4]$. Ekspozycja na nadmierne dawki fluorków we wczesnym dzieciństwie może być przyczyną zaburzeń mineralizacji zebów istotnych z punktu widzenia estetyki i późniejszej odporności na patologiczne procesy tkanek twardych zęba $[5,7]$. Obserwowany wzrost liczby przypadków fluorozy szkliwa zarówno na terenach z fluorkowaną wodą pitną, jak i na terenach z niską zawartością fluorków w wodzie pitnej świadczy o znaczącym zwielokrotnieniu kontaktu człowieka z fluorkami prawdopodobnie na skutek zanieczyszczenia środowiska, importu i eksportu żywności oraz rozpowszechnienia fluorkowych środków do profilaktyki próchnicy [7-11].

Uzasadnieniem poszukiwań innych niż jony fluorkowe systemów do remineralizowania szkliwa jest niska skuteczność tych pierwszych w przypadku kwasowego pH w jamie ustnej (zwłaszcza poniżej 4,5), zmniejszonej aktywności gruczołów ślinowych i niedostatecznej ilości śliny w jamie ustnej oraz niekorzystnej, selektywnej remineralizacji szkliwa ograniczonej do warstw powierzchniowych $[12,13]$.

Powyższe argumenty przyczyniły się do rozwoju badań nad niefluorkowymi środkami do remineralizacji zębów, które mają nie tylko wspomagać walkę z chorobą próchnicową, ale wykazywać nietoksyczność, a nawet biomimetyczność w stosunku do organizmu człowieka.

Wśród wprowadzonych obecnie do sprzedaży komercyjnej należy wyróżnić takie środki, jak fosforan trójwapniowy (TCP), fosforokrzemian wapniowo-sodowy, arginina-węglan wapnia, amorficzny fosforan wapnia oraz nanohydroksyapatyt (HA/HAP) [14].

\section{Fosforan trójwapniowy (TCP)}

Chemiczny mechanizm działania systemu remineralizacyjnego TCP polega na funkcjonalizacji polihydrolizowanego tlenku wapnia wraz ze specyficznymi cząsteczkami organicznymi (kwasem fumarowym, laurylosiarczanem sodu). Następnie dochodzi do współdziałania i interakcji z fluorkami w celu polepszenia jakości i tworzenia wiązań z luźno związanymi lub przerwanymi grupami ortofosforanowymi w usieciowanej strukturze szkliwa. Udowodniono, że kombinacja TCP i fluorków w żelach, pastach i lakierach powoduje remineralizację początkowych zmian próchnicowych i erozji szkliwa, czyniąc je odporniejszymi na kwasy. Nadal jednak nie zostało ustalone, jakie stężenie jonów fluorkowych powinno być dodane do TCP, aby zagwarantowana była skuteczność tych środków [14].

\section{Fosforokrzemian wapniowo-sodowy na bazie szkła CPSP (Novamin)}

Pierwotnie ten związek był dedykowany przeciw nadwrażliwości bólowej zębiny narażonej na ekspozycję kanalików zębinowych. Formuła chemiczna występowała $w$ wielu pastach do zębów do codziennego szczotkowania. Późniejsze badania in vitro wykazały jego zastosowanie w remineralizacji szkliwa poprzez stopniowe uwalnianie sodu, wapnia i fosforanów do jamy ustnej, gdzie następnie współdziałając ze śliną, dochodzi do formowania kryształów hydroksywęglanów podobnych do apatytów szkliwa. Szkło chroni wapń i fosforany przed przedwczesnym przereagowaniem. Wykazano, że połączenie fosforokrzemianów wapniowo-sodowych z odpowiednią dawką fluorków zwiększa remineralizację szkliwa lepiej niż pojedyncze cząsteczki samego szkła [15, 16].

\section{Dwuwodorowęglan argininy}

Dwuwodorowęglan argininy to kompleks aminokwasowy połączony z cząsteczkami wapnia, a także monofluorofosforanem sodu. Połączenie argininy ze związkami fluoru zwiększa efektywność działania przeciwko próchnicy szkliwa i korzenia, a także zmniejsza nadwrażliwość zębiny [17]. Na rynku środków do higieny jamy ustnej dwuwodorowęglan argininy występuje $\mathrm{w}$ stężeniach 1,5\% w paście przeciwpróchnicowej lub $8 \%$ w połączeniu z jonami wapnia i monofluorofosforanów (MFP) przeciwko nadwrażliwości zębiny.

Wykazano, że pasta do zębów zawierająca 1,5\% argininy i nierozpuszczalnej formy wapnia wraz z 1450 ppm fluoru zapewnia wyższą skuteczność w utrzymywaniu się i cofaniu zmian próchnicowych u dorosłych w porównaniu ze środkiem zawierającym sam fluor [14].

W badaniach in vitro stężenie $8 \%$ kompleksu argininy z węglanem wapnia wpływa na zamykanie kanalików zębinowych około $80 \%$, a po aplikacji kwasu cytrynowego nie dochodzi do ich otwarcia, nadal około 54\% kanalików zębinowych pozostawało całkowicie zamkniętych. Mechanizm ochrony i obturacji kanalików polega na adherencji cząsteczek węglanu wapnia do zdemineralizowanej powierzchni za pomocą kompleksu argininy. Rozpuszczanie węglanu wapnia i uwalnianie jonów wapnia zapewnia ciągłą remineralizację, a jony wodorowęglanowe podwyższają $\mathrm{pH}[18,19]$. Kompleksowi argininy przypisuje się 
właściwości przeciwbakteryjne dzięki obecności niepatogennych bakterii jamy ustnej, podatnych na działanie argininy, tzw. "arginolytic bacteria”, m.in. S. Sanguis, jest ona metabolizowana do zasadowego amoniaku. Reakcja ta wyzwala obniżenie potencjału kwasotwórczego płytki bakteryjnej i śliny oraz tworzenie bakteryjnego biofilmu [20].

\section{Fosfopeptyd kazeiny - amorficzny fosforan wapnia (CPP-ACP lub CPP-ACFP)}

Fosfoproteina (CPP-ACP) ma za zadanie dostarczać do środowiska jamy ustnej jony wapnia i fosforanów oraz stabilizować przesycony roztwór amorficznego fosforanu wapnia w ślinie. Stąd za pomocą utworzonego rezerwuaru jonów wapnia i fosforanów możliwe jest utworzenie wolnych cząsteczek amorficznego fosforanu wapnia $z$ fosfopeptydu kazeiny [21]. Dodatkowo do amorficznego fosforanu wapnia może zostać dostarczony fluor, przez co powstaje związek o podobnych właściwościach mineralizacyjnych: CPP-ACFP. Oba związki CPP-ACP i CPP-ACFP posiadają zdolności przechodzenia do powierzchni szkliwa na zasadzie dyfuzji wysokich stężeń jonów wapniowych i fosforanowych do zdemineralizowanej zmiany znajdującej się pod powierzchniową warstwą szkliwa, a w obecności fluoru formują się również fluoroapatyty [22]. W efekcie dochodzi do zahamowania demineralizacji i pobudzenia remineralizacji poprzez:

> tworzenie się nasyconej w jony wapnia i fosforanów warstwy,

> modyfikację dynamiki procesu demineralizacji i remineralizacji procesu próchnicowego,

> rozkład enzymatyczny kompleksu CPP-ACP, CPP-ACFP, co wpływa na zwiększenie się pH w płytce bakteryjnej i prowadzi do wytworzenia się zasadowych związków amoniaku,

> CPP-ACP sprzyja również remineralizacji szkliwa zdemineralizowanego poprzez proces erozji [23].

\section{Nanohydroksyapatyt (HA)}

Użycie hydroksyapatytów w początkowej fazie próchnicy zębów zostało potwierdzone laboratoryjnie i w randomizowanych badaniach klinicznych już od lat 90. ubiegłego stulecia [24]. Uszkodzone miejsca w wyniku rozpadu próchnicowego mogą zostać uzupełnione reparacyjnym hydroksyapatytem, tak na drodze wymiany jonowej, jak i mechanicznego wbudowywania. Podczas tego procesu naprawczego powstaje biomimetyczna warstwa na powierzchni szkliwa, która naturalnie uzupełnia strukturę szkliwa, naśladując aktywność powierzchniową szkliwa. Bez względu czy jest to utrata minerałów na skutek próchnicy, obnażenia zębiny czy erozji związki HA osadzają się przede wszystkim w miejscach gdzie ich ubywa. Z roztworu remineralizującego przyciągane są jony wapniowe i fosforanowe, które stymulują wzrost i integralność kryształów nanohydroksyapatytu [25, 26].

Działanie remineralizacyjne HA wzrasta wraz z jego stężeniem. Po przekroczeniu stężenia $10 \%$ utrzymuje się efekt plateau. Jak dotąd nie wykazano zależności między dawką a efektywnością działania HA, tak jak w przypadku związków fluoru, co daje hydroksyapatytom przewagę oraz wielokierunkowe możliwości zastosowania $\mathrm{w}$ prewencji różnych procesów patologicznych zębów [27].

Istotną obserwacją ostatnich lat jest fakt, że związki fluorkowe powodują wzmocnienie działania HA i zwiekszają potencjał odbudowy kryształów szkliwa poprzez wymianę z grupami hydroksylowymi [14, 26].

Badania w kierunku potwierdzenia właściwości antybakteryjnych HA wykazały, że ich obecność ma wpływ antyagregacyjny oraz antyadhezyjny na kolonizację bakterii do powierzchni szkliwa. Działanie przeciwbakteryjne HA może utrzymywać się przez około 8 godzin od aplikacji. W sprzedaży komercyjnej do środków do higieny jamy ustnej z HA dodano związki cynku ZnO lub Zn, mające hamować tworzenie się biofilmu bakteryjnego. Jednakże w badaniach Harksa i wsp. wykazano, że połączenie HA z jonami cynku wpływa na ograniczenie rozwoju choroby przyzębia, jednak nie wykazano różnicy z grupą porównawczą związków fluorowych $\left(\mathrm{AmF} / \mathrm{SnF}_{2}\right)$ [28]. Dlatego ocena właściwości antybakteryjnych HA wymaga jeszcze dalszych eksploracji.

Niezaprzeczalną zaletą syntetycznego HA jest jego biozgodność, krystaliczna struktura i brak kancerogenności i niekorzystnych reakcji ze strony organizmu człowieka, potwierdzone przez wielu badaczy i szereg doświadczeń. Nie wykazano także zależności HA od stężenia lub wahań pH środowiska jamy ustnej, a zaburzone wydzielanie śliny nie wpływa na obniżenie potencjału odtwórczego HA. Ważna jest właściwość HA polegająca na niezależnej remineralizacji szkliwa zębów bez koniecznej obecności w tym procesie jonów fluoru.

\section{Wnioski}

, Podsumowując bieżący stan wiedzy na temat aktualnie dostępnych niefluorkowych związków remineralizacyjnych, wydaje sie, że największe znaczenie mają obecnie nanocząsteczki HA i CPP-ACFP. 
, Olbrzymia ilość badań na temat innych niż fluorki materiałów remineneralizacyjnych przekonuje o możliwości ich stosowania w stomatologii zapobiegawczej.

, O ich skuteczności decydują odporność na wahania pH środowiska jamy ustnej, zdolność do wymiany jonowej i biomimetyczność tych związków.

, Materiały te działają synergistycznie w stosunku do fluoru, a niektóre z nich wykazują lepszą skuteczność w połączeniu z jonami fluorkowymi, stąd można je nazywać systemami do remineralizacji zębów.

Ważne, aby w dalszym ciągu kontynuować kierunki badań in vivo na bazie przedstawionych systemów w celu precyzyjnej oceny ich biologicznych oddziaływań w jamie ustnej.

\section{Oświadczenia}

Oświadczenie dotyczące konfliktu interesów Autorzy deklarują brak konfliktu interesów w autorstwie oraz publikacji pracy.

\section{Źródła finansowania}

Autorzy deklarują brak źródeł finansowania.

\section{Piśmiennictwo}

[1] Ellwood R, Fejerskov O. Zastosowanie kiniczne fluorków. Próchnica zębów. Choroba próchnicowa i postępowanie kliniczne. Wyd anie I polskie pod red. Urszuli Kaczmarek. Wydaw nictwo Medyczne Urban \& Partner, Wrocław. 2006.

[2] Centers for Disease Control and Prevention. Recommendations for using fluoride to prevent and control dental caries in the United States. MMWR 2001;50:-42.

[3] US Institute of Medicine. Standing Committee on the Scientific Evaluation of Dietary Reference Intakes. Dietary Reference Intakes for Calcium, Phosphorus, Magnesium, Vitamin D, and Fluoride. Washington. 1997, National Academy Press.

[4] Levy SM. An Update on Fluorides and Fluorosis. J Can Dent Assoc. 2003;69:286-91.

[5] Pendrys DG. Risk of enamel fluorosis in nonfluoridated and optimally fluoridated populations: considerations for the dental professional. J Am Dent Assoc. 2000;131:746-55.

[6] Opydo-Szymaczek J, Gerreth K. Enamel fluorosis and its association with dental caries in a nonfluoridated community of Wielkopolska, Western Poland. Fluoride. 2013;46:234-8.

[7] Borysewicz-Lewicka M, Opydo-Szymaczek J, Opydo J. Fluoride ingestion after brushing with a gel containing a high concentration of fluoride. Biological Trace Elements Res. 2007;120:114-120.

[8] Opydo-Szymaczek J, Opydo J. Salivary fluoride concentrations and fluoride ingestion following application of preparations containing high concen- tration of fluoride. Biological Trace Elements Res. 2010;137:159-67.

[9] Opydo-Szymaczek J, Opydo J. Assessment of fluoride exposure following application of toothpaste containing high concentration of fluoride. Trace Elements and Electrolytes. 2010;27:214-219.

[10] Opydo-Szymaczek J. Fluoride Exposure from Diet in Infants and Young Children Fed with the Foodstuffs for Particular Nutritional Use. Dent Med Probl. 2012;49:209-215.

[11] Opydo-Szymaczek J, Gerreth K. Etiological factors related to dental fluorosis among children in Poznan, Poland - a preliminary report. Fluoride. 2012;45:354- 359.

[12] Biesbrock AR, Faller RV, Bartizek RD, Court LK, McClanahan SF. Reversal of incipient and radiographic caries through the use of sodium and stannous fluoride dentifrices in a clinical trial. J Clin Dent. 1998;9(1):5-10.

[13] Ten Cate JM. Fluorides in caries prevention and control: empiricism or science. Caries Res. 2004;38(3): 254-7.

[14] Amaechi BT, van Loveren C. Fluorides and non-fluoride remineralization systems. Monogr Oral Sci. 2013;23:15-26. doi: 10.1159/000350458. Epub. 2013 Jun 28.

[15] Chałas R, Wójcik-Chęcińska I, Zamościńska J, Bachanek T. Assessment of Pain Intensity in Patients with Dentin Hypersensitivity After Application of Prophylaxis Paste Based on Calcium Sodium Phosphosilicate Formula. Med Sci Monit. 2015;21(1):2950-5. doi: 10.12659/MSM.894189.

[16] Wang Y, Mei L, Gong L, Li J, He S, Ji Y, Sun W. Remineralization of early enamel caries lesions using different bioactive elements containing toothpastes: An in vitro study. Technol Health Care. 2016 Sep 14;24(5):701-11. doi: 10.3233/THC-161221.

[17] Hu DY, Yin W, Li X, Feng Y, Zhang YP, Cummins D, et al. A clinical investigation of the efficacy of a dentifrice containing $1.5 \%$ arginine and. 1450 ppm fluoride, as monofluorophosphate, in a calcium base on primary root caries. J Clin Dent. 2013;24(Spec Iss A): A23-31.

[18] Nascimento MM, Gordan VV, Garvan CW, Browngardt CM, Burne RA. Correlations of oral bacterial arginine and urea catabolism with caries experience. Oral Microbiol Immunol. 2009;24:89-95.

[19] Wijeyeweera RL, Kleinberg I. Arginolytic and ureolytic activities of pure cultures of human oral bacteria and their effects on the $\mathrm{pH}$ response of salivary sediment and dental plaque in vitro. Arch Oral Biol.1989;34:43-53.

[20] Koopman JE, Hoogenkamp MA, Buijs MJ, Brandt BW, Keijser BJ, Crielaard W, Ten Cate JM, Zaura E. Changes in the oral ecosystem induced by the use of $8 \%$ arginine toothpaste. Arch Oral Biol. 2017 Jan;73:79-87. doi: 10.1016/j.archoralbio.2016.09.008. Epub. 2016 Sep 26.

[21] Navneet G, Cinod K, Sukrit G. Surface remineralization potential of casein phosphopeptide-amorphous calcium phosphate on enamel eroded by 
cola-drinks: An in-situ model study Contemp Clin Dent. 2013;4(3): 336-42.

[22] Cochrane NJ, Saranathan S, Cai F, Cross KJ, Reynolds EC. Enamel subsurface lesion remineralisation with casein phosphopeptide stabilised solutions of calcium, phosphate and fluoride. Caries Res. 2008;42(2):88-97. doi: 10.1159/000113161. Epub. 2008 Jan 15.

[23] Roveri, N, Battistella, E, Bianchi, CL, Foltran, I, Foresti, E, lafasco, M, et al. (2009a). Surface enamel remineralization: biomimetic apatite nanocrys- tals and fluoride ions different effects. J Nanomater. 2009;1-9. ID 746383,doi: 10.1155/2009/746383.

[24] Huang SB, Gao SS, Yu HY. Effect of nano-hydroxyapatite concentration on remineralization of initial enamel lesion in vitro. Biomed Mater. $2009 \mathrm{Ju}-$ n;4(3):034104. doi: 10.1088/1748-6041/4/3/034104. Epub. 2009 Jun 5.

[25] Mielczarek A, Michalik J. Wpływ pasty z nanohydroksyapatytem na mikrotwardość powierzchni szkliwa z próchnicą początkową - badania in vitro, NOWA STOMATOLOGIA 2013,2: 77.

[26] Lelli M, Putignano A, Marchetti M, Foltran M, Mangani F, Procaccini M, Roveri N, Orsini G. Remineralization and repair of enamel surface by biomimetic Zn-carbonate hydroxyapatite containing toothpaste: a comparative in vivo study. Front Physiol. 2014 Sep 5;5: 333. doi: 10.3389/fphys.2014.00333. eCollection. 2014.

[27] Orsini G, Procaccini M, Manzoli L, Giuliodori F, Lorenzini $A$, Putignano $A$. A double-blind randomized-controlled trial comparing the desensitizing efficacy of a new dentifrice containing carbonate/
Plaque Formation and Dentifrice hydroxyapatite nanocrystals and a sodium fluoride/potassium nitrate dentifrice. J Clin Periodontol. 2010;37(6):510-7. Epub. 2010/05/29. doi: 10.1111/j.1600-051X.2010.01558.x PMID:20507374.

[28] Harks I, Jockel-Schneider Y, Schlagenhauf U, May TW, Gravemeier M, Prior K, et al. Impact of the Daily Use of a Microcrystal Hydroxyapatite Dentifrice on De Novo Plaque Formation and Clinical/Microbiological Parameters of Periodontal Health. A Randomized Trial. 2016 PLoS ONE 11(7): e0160142. doi:10.1371/ journal.pone.0160142.

Zaakceptowano do edycji: 2018-10-16 Zaakceptowano do publikacji: 2018-12-05

\section{Adres do korespondencji:}

Zakład Stomatologii Zintegrowanej

Uniwersytet Medyczny im. Karola Marcinkowskiego w Poznaniu

ul. Bukowska 70, 60-812 Poznań

tel.: 618547027

e-mail: paszynska@ump.edu.pl 